\title{
THE CONCEPT OF PUBLIC POLICY IN THE ECO SWISS DECISION OF THE COURT OF JUSTICE OF THE EUROPEAN UNION AND ITS IMPACT ON THE INTRA-EU INVESTMENT TREATY ARBITRATIONS
}

\author{
AVRUPA BİRLIĞİ ADALET DIVANININ ECO SWISS KARARINDAKİ KAMU DÜZENI KAVRAMI \\ VE BUNUN AB İÇI YATIRIM ANTLAŞMASI TAHKIMLERINDEKİ ETKISI
}

\author{
Kazım Sedat SIRMEN* ${ }^{*}$ (iD
}

\begin{tabular}{l} 
Makale Bilgi \\
Gönderi: 05/05/2021 \\
Kabul :08/07/2021 \\
Anahtar Kelimeler \\
\hline Kamu Düzeni, \\
Emredici Kurallar, \\
Eco-Swiss, \\
Achmea, \\
PL v.Poland.
\end{tabular}

Article Info

Received: 05/05/2021 Accepted: 08/07/2021

\section{Keywords}

Public Policy, Mandatory Rules, Eco-Swiss, Achmea, PL v.Poland.

\begin{abstract}
Özet
https://dai.org//0.21492/inuhfd.933007 do

Kamu düzeninin ilginç tanımlarından birini, Amerikan Federal Yüksek Mahkemesi Yargıcı Cardozo'nun kararında görmekteyiz. Cardozo'ya göre, yabancı devletin hâkimi, kendi ülkesinde var olan temel adalet şuurunu, ortak yaygın ahlak anlayışını ve köklü ortak iyilik anlayışını ihlâl etmedikçe yabancı hukuku reddedemez. Milletlerarası Özel Hukukta for yargıcı, kamu düzeni anlayışının harekete geçmesi gerektiği kanısına varırsa, artık milletlerarası özel hukuk menfaatini ikinci plana atıp maddî hukuk menfaatini ön plana alabilir. Kamu düzeni kavramının, kanunlar ihtilâfı hukukunda, yabancı hakem veya mahkeme kararlarının tanınması ve tenfizinde farklı işlevleri vardır. Öte yandan, kamu düzenine başvurmak istisnaî olmalıdır ve işte bu, kamu düzenini, emredici kurallardan ayıran temel kriterlerden biridir. Bu ayrım, Eco Swiss davasında Avrupa Birliği Adalet Divanı tarafından tam olarak ortaya konulamamış ve Divan, Avrupa Birliği Antlaşmasındaki emredici rekabet hukuku kurallarını kamu düzeni kavramı içerisinde nitelendirmiştir. Bununla birlikte, $\mathrm{AB}$ içi yatırım tahkimi kararlarına karşı millî mahkemeler nezdinde başvurulan hakem kararlarını iptal taleplerinde kamu düzeni kavramı daha doğru yorumlanmış ve hakimler, hakem kararlarının iptalinde kamu düzenine başvurmamışlardır.
\end{abstract}

\begin{abstract}
One of the interesting definitions of public policy was seen in the quoted passage of the US Supreme Court Judge Cardozo. According to Cardozo, foreign judge shall not discard the foreign law unless it violates some fundamental principle of rights, some common conception of good morals, some deep-rooted tradition of the common weal. In private international law, especially when the forum judge needs to functionalize the notion of public policy, the interest of the private international law may stay behind the interests of substantial law. Public policy has different functions in conflicts of law and in the recognition and enforcement of arbitral awards or court decisions. On the other hand, triggering off the institution of the public policy must be exceptional, and this is the most important distinction between the public policy and the mandatory rules. This distinction could not be pointed out properly in Eco Swiss case where the Court of Justice of European Union (CJEU) has qualified the mandatory rules of competition law in the Treaty within the concept of public policy. In the subsequent court decisions that supervise the intra-EU investment arbitral awards, however, the concept of public policy was interpreted more accurately, and the judges did not prefer to apply the concept of public policy to set aside the arbitral awards.
\end{abstract}




\section{INTRODUCTION}

In general, a legal system has four aspects: the legislative, judicial, executive organs and the norms that are applied to life and human relations. The national legal system can be regarded as the perfect organization of these aspects. On the other hand, we have another legal system that is concerned with "international society" called the international legal system. Unfortunately, the organization of the aspects of that system is weak, so a national legal system may sometimes intervene into the "soul" of the international legal system.

The advanced outlook of the "life and human relations" of the international society is mostly seen in commercial activities. The actors, coming from separate national legal systems, conclude transnational commercial relations and create their own norms and organs, so long as these aspects of the international legal system do not infringe the basic principles of the national legal systems. International commercial arbitration could be given as an example of the dispute resolution mechanism applied to the conflicts arising from international commercial interactions. Although we can see the autonomy of the parties in international commercial arbitration, the awards are ultimately supervised by the national courts. Moreover, national courts may set aside the awards or may not recognize or enforce them if certain conditions are not met.

In this article, after a short overview regarding the notion of public policy, I will first focus on the jurisprudence on public policy of the Court of Justice of the European Union (CJEU). Within this jurisprudence, the Eco Swiss decision of CJEU, which has been criticized and deemed as a challenge to the enforcement and recognition of intra-EU arbitral awards will be discussed. Lastly, the citations of this decision in two of the intra-annulment requests of an Intra EU Investment Arbitral Awards will be addressed.

\section{PUBLIC POLICY}

\section{A.The function of Public Policy in Private International Law}

Public policy has several functions in private international law. The first function is in conflicts of law. In the application of foreign law, the function of the public policy is to preclude the court from applying a rule of foreign law. In this context, national courts do not compare the provisions of foreign law and the law of forum. Forum has a commitment to find whether the result of the application of foreign law infringed the main notions or basic values that are comprised in the formation of the positive law ${ }^{1}$.

We can find the second function of the public policy notion in recognition and enforcement process of either foreign courts judgments or foreign arbitral awards ${ }^{2}$. In this context the judge of the country where the recognition and enforcement take place does not have the responsibility to determine whether the rule that was applied to the conflict infringed the "public policy" of his State. The judge must take into consideration the implications of the court decisions or arbitral awards. If these are against public policy- whether substantive or procedural- then the judge may refuse the request of the successful party for the recognition and enforcement of the court decision or arbitral award.

In the first function of the public policy, court discusses the consequences of the application of the "foreign rule". On the other hand, in the second function of the public policy, although the foreign court or arbitral tribunal applies the law of the State to the case of which the recognition and

\footnotetext{
1 GRUSIC, Uglješa/HEINZE, Christian/MERRETT, Louise/MILLS, Alex/GARCIA-CASTRILLON, Carmen Otero/TANG, Zheng Sophia/TRIMMINGS, Katarina/WALKER, Lara: Cheshire, North \& Fawcett Private International Law-Edited by Paul Torremans, Ed.15, OUP, New York 2017, p.133; ŞANLI, Cemal/ESEN, Emre/ATAMAN FİGANMEŞE, İnci: Milletlerarası Özel Hukuk, Bası.8, Vedat Kitapçılık, İstanbul 2020, p.78; HAY, Peter: Advanced Introduction to Private International Law and Procedure, Edward Elgar Publishing, Cheltenham/Northampton 2018, p.97; GÜNGÖR, Gülin: Türk Milletlerarası Özel Hukuku-Kanunlar İhtilafı Hukuku Milletlerarası Usul Hukuku, Yetkin Yayınları, Ankara 2021, s.104; NOMER, Ergin: Devletler Hususi Hukuku, 22.Bası, Beta Yayınları, İstanbul 2017, s. 164 vd; TEKİNALP, Gülören: Milletlerarası Özel Hukuk Bağlama ve Usul Hukuku Kuralları, 13.Bası, Vedat Kitapçılık, İstanbul 2020, s.45; ÇELİKEL, Aysel/ERDEM, Bahadır: Milletlerarası Özel Hukuk, 14.Bası, Beta Yayınları, İstanbul 2016, s. 150 vd; AKINCI, Ziya: Milletlerarası Özel Hukuk, Vedat Kitapçılık, İstanbul 2020, s. 20.

2 DEMIR GÖKYAYLA, Cemile: Yeniden Kamu Düzeni, Onuncu Yılında MOHUK Sempozyumu, in Tanrıbilir, Feriha Bilge/Gümüşlü Tunçă̆ıll, Gülce (ed.), Sempozyum 7-8 Aralık 2017, Adalet Yayınevi, Ankara 2018, s.87.
} 
enforcement is requested; the recognition or enforcement of this court decision or arbitral award may also be refused for example, if there is an infringement of fair trial in this case ${ }^{3}$.

Lastly, the third function of the notion of public policy is seen mostly in national arbitration legislation, not only in provisions for "non-recognition" but also in those for "annulment". Foreign and non-domestic awards that violate public policy may be annulled in national courts. Most importantly, the courts of the "seat of arbitration" are entitled to annul arbitral awards based on national arbitration rules that introduce the "public policy violation" into their regulations ${ }^{4}$.

\section{B. Types of Public Policy}

There are three types of public policy that may be considered in international commercial arbitration: National (domestic), international and transnational. According to this distinction, national public policy refers to the very fundamental notions and postulates of morality and justice introduced in that local system and that are appropriately applied to transactions or relationships particular to that jurisdiction ${ }^{5}$. These rules are designed to protect the public interests of that State $^{6}$.

International public policy must be understood more narrowly than the national public policy. Fundamental notions of morality and justice identified by the national governments and courts are applied to disputes that have an international character. International public policy could be the subject matter of private international $\mathrm{law}^{7}$. According to the International Law Association Committee on International Commercial Arbitration, international public policy is the body of principles and rules recognized by a State, which, by their nature, may bar the recognition or enforcement of an arbitral award rendered in the context of international commercial arbitration when recognition or enforcement of the award would entail their violation on account either of the procedure pursuant to which it was rendered (procedural public policy) or its content (substantive international public policy $)^{8}$.

The last type of public policy is transnational public policy. It is derived from the principles that are commonly recognized by political and legal systems around the world. There is some agreement that they comprise fundamental rules of natural law, principles of universal justice, jus cogens in public international law, and the general principles of morality accepted by what are referred to as civilized nations". Dolinger, defines it as a "world public policy" that establishes universal principles, in various fields of international law and relations, to serve the higher interests of the world community, the common interests of mankind, above and sometimes even contrary to the interests of individual nations ${ }^{10}$. If we compare the transnational public policy with the international public policy, we will see that the notions of international public policy derive from the perceptions of the sovereign states while transnational public policy represents the common fundamental values of the world community. Notions of transnational public policy do not belong to one State ${ }^{11}$.

Courts generally do not employ the distinction, at least not in the context of the recognition or enforcement of foreign arbitral awards. Public policy may vary from time to time and country to

\footnotetext{
${ }^{3}$ TİRYAKIOĞLU, Bilgin.: Yabancı Mahkeme Kararlarının Tanınması ve Tenfizinde Kamu Düzenine Aykırılık, Yabancı Mahkeme ve Hakem Kararlarının Tanınması ve Tenfizinde Güncel Gelişmeler, Edt. Süheyla Balkar BOZKURT, Sempozyum 14 Ekim 2016, On iki Levha, İstanbul 2018, s.84.

${ }^{4}$ Some authors submitted that "public policy" for purposes of annulment of an award should be exactly the same as "public policy" in recognition actions under the New York Convention. On the other hand, in some decisions, public policy for the purpose of recognition under New York Convention should be even more limited than that in an annulment action under national law: BORN, Gary, International Commercial Arbitration, Vol.III, Ed.3, Wolters Kluwer, Alphen aan den Rijn 2021, p.3610; AKINCI, Ziya: Milletlerarası Tahkim, 5.Baskı, Vedat Kitapçılık, İstanbul 2020, s.375.

${ }^{5}$ SHENOY, Nivedita: "Public Policy under Article V (2)(b) of the New York Convention: Is there a Transnational Standard", Cardozo Journal of Conflict Resolution, XX, 2018, p.80; LALIVE, Pierre: "Transnational (or Truly International) Public Policy and International Arbitration", in Comparative Arbitration Practice and Public Policy in Arbitration, ICCA Congress Serles, III, 1986, Kluwer Law International, Aan den Rijn 1987, p.258.

${ }^{6}$ FRY, James: "Desordre Public International under the New York Convention: Wither Truly International Public Policy", Chinese Journal of International Law, VIII, 2009, p.86.

${ }^{7}$ PARK, William: The Specificity of International Arbitration: The Case for FAA Reform, Vanderbilt Journal of Transnational Law, XXXVI, 2003, p.1272, sn.138.

${ }^{8}$ MAYER, Pierre/SHEPPARD, Audley: "Final Report on Public Policy as a Bar to Enforcement of International Arbitral Awards", Arbitration International, XIX, 2003, p.253

${ }^{9}$ LALIVE, p.307.

10 DOLINGER, Jacob: "World Public Policy: Real International Public Policy in the Conflict of Laws", Texas International Law Journal, XVII(II) Spring 1982, p.172.

${ }^{11}$ BUCHANAN, Mark A.: "Public Policy and International Commercial Arbitration", American Business Law Journal, XXVI (III), Fall 1988, p.514. Some commentators divide the public policy into two parts if the notions of public policy
} 
country $^{12}$. The public policy exception to enforcement must be construed narrowly; courts that receive a request to recognize and enforce arbitral awards may not refuse their recognition and enforcement solely based on illegality, national legislation, or fundamental principles of law. Courts are not entitled to re-examine foreign arbitral awards ${ }^{13}$.

Public policy is the final parameter of the law that, while it is reflected in and often expressed by statutory and constitutional statements of law, also dictates either consent or constraint, permission, or prohibition, when statutes and constitutions are silent on a given matter. Public policy first exists at the domestic level within each individual state. Here, public policy represents those local standards or rules that are not subject to alteration or derogation by the parties and stand as an outside limit to the parties' freedom to contract. Accordingly, the courts, either in an adjudicatory role or as enforcers of arbitral awards, may relieve a party from contractual duties or impose additional duties where a state's "most basic notions of morality and justice" require it.

\section{APPROACH OF CJEU TO THE PUBLIC POLICY CONCEPT}

\section{A. Eco Swiss Case $^{14}$}

Through this case, CJEU had an opportunity to address arbitral decisions from the perspective of the fundamental norms of EU Law, under the concept of public policy. In 1997, the Hoge Raad der Nederlanden (Supreme Court of the Netherlands) referred to the CJEU for a preliminary ruling under Article 267 of Treaty on the Functioning of the European Union- (TFEU) ${ }^{15}$ regarding questions about the interpretation of Article 101 of the TFEU ${ }^{16}$. Those questions were raised in proceedings brought by Benetton International NV ('Benetton') for the court to set aside the arbitration award ordering Benetton to pay damages to Eco Swiss China Time Ltd ('Eco Swiss') for breach of a licensing agreement by the Supreme Court of the Netherlands. Since seat of arbitration is in Netherlands, Article 1065(1)(e $)^{17}$ of the Wetboek van Burgerlijke Rechtsvordering (hereinafter referred to as the Code of Civil Procedure) had to be applied, on the ground that the award in question was contrary to public policy under Article 101 of the TFEU.

The Supreme Court asked CJEU five questions in total, but the question regarding "public policy" is the important one for our subject ${ }^{18}$. According to the CJEU, Article 3 (1)(b) of the TFEU ${ }^{19}$ is an essential provision and must be regarded as a fundamental principle of the EU. This provision is so important, and its function is to provide for the accomplishment of the functions allocated to the Community and for the operation of the internal market. This Article also shows its function in

emanate from the sovereign states then, it is called national public policy which consists of domestic and international public policy,if the notions are emanated from supranational sources then it is called supranational public policy that is divided into transnational, regional and truly international public policy: FRY, p.86-89.

${ }^{12}$ Even the member States of European Union are free to determine the public policy conception, as we can see at the CJEU decision in Krombach v. Bamberski case that the limits of the "unstable" and "varianted time to time" public policy conceptions are required to be reviewed by the courts of the Member States: Judgment of the Court of 28 March 2000. Dieter Krombach v André Bamberski, European Court Reports 2000 Page I-01935.

13 MAURER, Anton.: The Public Policy Exception under the New York Convention-History, Interpretation and Application, Revised Edition, JurisNet, New York 2013, p.55.

${ }^{14}$ Eco Swiss China Time Ltd v Benetton International NV. - Reference for a preliminary ruling: Hoge Raad - Netherlands.: Case C-126/97, European Court Reports, 1999, I-03055 (Eco Swiss Case).

${ }^{15}$ Consolidated versions of the Treaty on European Union and the Treaty on the Functioning of the European Union Consolidated version of the Treaty on the Functioning of the European Union - Protocols - Annexes - Declarations annexed to the Final Act of the Intergovernmental Conference which adopted the Treaty of Lisbon, signed on 13 December 2007 - Tables of equivalences, OJ, C 326, 26/10/2012, P.001-390. Preliminary ruling is introduced in Article 177 of the EC Treaty (Maastricht Consolidated Version) and Article 234 of the TEC (Amsterdam Consolidated Version). ${ }^{16}$ Article 85 of the EC Treaty (Maastricht Consolidated Version), later Article 81 of the TEC (Amsterdam Consolidated Version) became Article 101 of the TFEU prescribes a rule regarding the agreements between undertakings that may affect trade between the Member States by preventing, restricting or distorting the competition.

${ }^{17}$ According to the art 1065 (1)(e) of the Code..." the award or the way it has been made is contrary to public policy or accepted principles of morality."

18 "If the court considers that an arbitration award is in fact contrary to Article 85 of the EC Treaty, must it, on that ground and notwithstanding the rules of Netherlands procedural law set out in paragraphs 4.2 and 4.4 above [according to which a party may claim annulment of an arbitration award only on a limited number of grounds, one ground being that an award is contrary to public policy, which generally does not cover the mere fact that through the terms or enforcement of an arbitration award no effect is given to a prohibition laid down by competition law], allow a claim for annulment of that award if the claim otherwise complies with statutory requirements"

${ }^{19}$ Article 3(g) of the EC Treaty (Maastricht Consolidated Version) later Article 3(1)(g) of the TEC (Amsterdam Consolidated Version), became article 3 (1)(b) of the TFEU pointed that establishing of the competition rules necessary for the functioning of the internal market is fallıng under the exclusive competence of European Union.... 
private law. Any agreements or decisions prohibited pursuant to that Article are considered to be automatically void.

We can easily assert that according to the CJEU, Article 101 of the TFEU as a fundamental mandatory rule of EU Law, is incorporated into the notion of public policy ${ }^{20}$. We can find public policy concerns not only in the in the set aside procedures of national laws but also in the recognition/enforcement process carried out according to the New York Convention of 10 June 1958 on the Recognition and Enforcement of Foreign Arbitral Awards, which has been ratified by all the Member States.

\section{B. Criticism of Eco Swiss Case}

In Eco Swiss Case, the CJEU first concentrated upon public policy and EU competition law . It began by pointing that the national courts of Member States must take into consideration any questions regarding EU Law in the process either of setting aside or recognizing and enforcing an award.

The CJEU findings related to Article 101 of the TFEU may inter alia be regarded as a matter of public policy under the New York Convention. In addition, when the rules of the annulment procedure of the seat of arbitration introduce public policy as a basis for annulment, the national court must vacant or set aside an arbitral award if it finds that the award infringes Article 101 of the TFEU $^{21}$.

The arbitrator's main task is to render an arbitral award that will not be set aside in the courts of the seat of arbitration and that will be enforceable in the State where the enforcement is sought ${ }^{22}$. That is what Kegel said was a kind of a legal order interest (ordnungsinteresse) ${ }^{23}$ that the courts or arbitral tribunals provide by rendering "recognizable and enforceable awards" 24 . In order to reach valid arbitral awards, arbitrators have to take into consideration "the fundamentally important mandatory laws and overriding public policies of the law of the seat of arbitration or the law of the country where the recognition/enforcement of the arbitral awards are sought" ${ }^{25}$ Disregarding mandatory laws and overriding public policies may be deemed as grounds for annulment, nonrecognition or non- enforcement of the arbitral awards.

The Eco Swiss case reveals us that the "public policy" which is taken into consideration by the national courts is the domestic public policy. This view is against the context that is seen in private international law. The trans-nationalization of law today could be realized by the arbitrators who could shield themselves from the influence of the law of the seat of arbitration. The resulting development of the doctrines of national, international, and transnational public policy in arbitration has been advanced with significant help from comparative law ${ }^{26}$, as Fumagalli pointed out, "public policy should be construed narrower than that of mandatory rules". Courts should not set aside or refuse the enforcement of the arbitral decisions by using the "public policy" concern as a weapon. Even if the arbitrators did not properly apply the mandatory rules of law their decisions should still

\footnotetext{
${ }^{20}$ KÁPOSZNYÁK, Aliz: "Intra-EU Arbitral Awards After Achmea: Recognition and Enforcement Within the European Union Under the New York Convention" in Z. Meškić et al. (eds.), Balkan Yearbook of European and International Law 2019, 2020, p.85.

${ }^{21}$ STORSKRUBB, Eva: "Navigating EU Law and the Law of Arbitration-From the Horizon of C ommercial Arbitration in Sweden”, In: Eric Bylander, Anna Jonsson Cornell, Jakob Rangwaldh (ed.), Forward! - Вперёд! - Framåt!: Essays in Honour of Prof Dr Kaj Hobér Uppsala: Iustus förlag, Uppsala 2019, s.289.

${ }^{22}$ BARRACLOUGH, Andrew/WAINCYMER, Jeff: "Mandatory Rules of Law in International Commercial Arbitration", Melbourne Journal of International Law, 6(2), 2005, s.215; HORVATH, Gunther J: "The Duty of the Tribunal to Render an Enforceable Award", Journal of International Arbitration 18(2), 2001, s.135.

${ }^{23}$ KEGEL, Gerhard/SCHURIG, Klaus: Internationales Privatrecht, 9. Auflage, Beck, München 2004, s.143 vd.

${ }^{24}$ TİRYAKİOLU, Bilgin: Taşinir Mallara İlişkin Milletlerarasi Unsurlu Satim Akitlerine Uygulanacak Hukuk, AÜHF Döner Sermaye Yayınları, Ankara 1996 (Taşınır), s.13; TEKINALP, s.29; GÜNGÖR, s.74.

${ }^{25}$ MAYER, Pierre: "Mandatory Rules of Law in International Arbitration", Arbitration International, 2 (4), 1986, s.282;BORN, Vol. III, p.3605.

26 JEMIELNIAK, Joanna: "Transnationalization of Domestic Law in International Commercial Arbitration Through Comparative Analysis: Challenges for Legal Profession, Contemporary Asia Arbitration Journal, 7(2), 2014, s.327.
} 
survive ${ }^{27}$. Moreover, courts have to consider the international public policy rather than national public policy. The "European public policy" should also be construed within this context ${ }^{28}$.

The views of Idot merits a special mention here. He pointed out that, for the Member States of the EU, Articles 101 and 102 of the TFEU could be considered undeniably as a part of the international public policy of the State where setting aside or enforcement is sought. This solution stems from the application of the principle of equivalence as strongly reaffirmed in the Eco Swiss judgment. The difficulties appear when the court decision is going to be enforced in a non-EU member State. If we deny the existence of a genuinely transnational public policy that would prevail worldwide, which would include, for example, universally accepted solutions in competition law, like the prohibition of cartels, it is not possible to monitor the respect by arbitrators of Community law in a third country ${ }^{29}$.

As it is submitted above that the best solution is to trans-nationalize the concept of public policy. By taking into consideration transnational public policy, we may serve the necessities of private international law perfectly.

\section{TWO COURT DECISIONS OF INTRA-EU INVESTMENT TREATY ARBITRATION AWARD AND THEIR APPROACH TO PUBLIC POLICY}

\section{A. Public Policy Perception in German Supreme Court (Bundesgerichtshof) Decision}

\section{General Overview}

The arbitral award which was rendered on 7 December 2012 between Achmea and Slovak Republic relied upon Article 8/(2) of the Agreement on encouragement and reciprocal protection of investments between the Kingdom of the Netherlands and the Czech and Slovak Federative Republic ('the BIT') ${ }^{30}$. According to Article 8/(2) of the BIT, each Contracting Party consents to submit a dispute [...] to an arbitral tribunal, if the dispute has not been settled amicably within a period of six months from the date on which either party to the dispute requested amicable settlement.

Arbitration proceedings commenced. Germany was chosen as a seat of arbitration and German law was applied to the proceedings. During the proceedings, Slovak Republic issued an objection related to the jurisdiction of the arbitral tribunal. The core of the objection is concerned with the inconsistency between Article 8(2) of BIT and the EU Law. The interim award of the arbitral tribunal was against the expectations of the Slovak Republic. Arbitral tribunal dismissed the objection.

On 7 December 2012, according to the arbitral award, ordered by the arbitral tribunal Slovak Republic was obliged to pay Achmea the damages in the principal amount of EUR 22.1 million $^{31}$.

The Slovak Republic ("Applicant") brought an action to set aside the award before the Higher Regional Court of Frankfurt (Oberlandesgericht Frankfurt am Main" -Higher Regional Court). The

\footnotetext{
${ }^{27}$ FUMAGALLI, Luigi: "Mandatory Rules and International Arbitration: An Italian Perspective", ASA Bulletin, 16(1), 1998, s.57. On the other hand esp in Turkish law, Supreme Court of Turkey have not construed the public policy narrowly and construed the mandatory rules within the notion of public policy in international commercial arbitration:EKŞİ, Nuray: "Yargıtay Kararları Işı̆̆ında Yabancı Hakem Kararlarının Tenfizinde Kamu Düzeni “, Public and Private International Law Bulletin, Prof. Dr. Cemal Şanlı’ya Armağan,40(1), 2020,s.176.

${ }^{28}$ This is also criticized by Bermann. According to Bermann "..." The CJEU has reason to entertain a highly robust conception of EU public policy for these purposes, since doing so serves to strengthen EU law's effectiveness within the national legal orders. But in that context, public policy cannot then be assumed to have the highly exceptional character ordinarily ascribed to it in private international law.:BERMANN, George A.: "Navigating EU Law and Law of Arbitration," Arbitration International, 28(3), 2012, s.420.

${ }^{29}$ IDOT, Laurence: "Arbitrage et droit de la concurrence", Revue des droits de la concurrence, Concurrences 4, 2010, note.64, s.14,www.concurrences.com, (Accessed:13.04.2021).

${ }^{30}$ Today, commencing an arbitration proceeding based on arbitration clauses that are prescribed in bilateral investment treaties is generally accepted: ATAMAN-FIGANMEŞE, İnci: "Devletlerarası Sözleşmelerde Yer Alan Tahkim Klozlarının Yatırımcılara Yapılmış Tahkim Anlaşması Akdetme Önerisi Olarak Kabulünün Ev Sahibi Devletler Bakımından Doğurduğu Olumsuz Sonuçlar", in ÖZDEMIR-KOCASAKAL, Hatice/BALKAR, Süheyla (ed.), Tahkim Anlaşması, On iki Levha Yayınları, İstanbul 2020, s.104. (Devletlerarası Tahkim Kloz). Ataman-Figanmeşe pointed out that by inserting an arbitration clause in bilateral treaties states provide each other investors an offer to conclude an arbitration agreement. If the investors do not accept the offer that is put into the bilateral investment treaties, the State will discard the provision in the treaty. In other words, by commencing a case before arbitral tribunals with the intention of the investor, then an arbitration agreement between the host State and the investor regarded as formed: ATAMANFIGANMEŞE, İnci: "Manufacturing Consent to Investment Treaty Arbitration By Means of the Notion of "Arbitration Without Privity" (Manufacture), Annales de la Faculte de Droit d'Istanbul, XLIII(LX), 2011, p.197.

${ }^{31}$ Judgment of the Court (Grand Chamber) of 6 March 2018 (request for a preliminary ruling from the Bundesgerichtshof — Germany) - Slowakische Republik v Achmea BV, Case C-284/16, OJ C161/07, 07.05.2018.
} 
Applicant claimed that the rule in Article 8(2) of the BIT was incompatible with EU law and thus the arbitral tribunal lacked jurisdiction. Higher Regional Court found no reason to overturn the award. It stated that the arbitration clause in Article 8 (2) of the BIT was valid because it was compatible with Union law. It does not infringe the exclusivity of the EU law dispute settlement mechanisms provided for in Article 344 of the TFEU because the Union treaties for disputes between a private investor and a Member State do not provide for a specific judicial procedure. Article 344 of the TFEU does not constitute a general "competence assurance rule" for the CJEU. The arbitration clause is also compatible with Article 267 of the TFEU. The arbitral tribunal was not able to submit to the CJEU questions relevant to the interpretation or application of Union law, according to the case law of the CJEU. However, it is sufficient that the state courts may review an award based on the restricted control measure provided in national law for annulment or refusal of recognition, in order to ensure the uniform interpretation and application of Union law in the Member States - if necessary, with the aid of a request for a preliminary ruling from the state courts to the CJEU. ${ }^{32}$ Subsequently, the Applicant lodged an appeal to the The Federal Court of Justice (Bundesgerichtshof-BGH), which in turn requested in March 2016 a preliminary ruling from the CJEU as to whether Articles 344 and 267 of the TFEU preclude the application of an investor-State arbitration clause in an intra-EU BIT. In its judgment of March 6, 2018, the CJEU ruled that an investor-State arbitration clause in an intra-EU BIT, such as Article 8(2) of the Treaty, adversely affects the autonomy of EU law and is incompatible with the duty of sincere cooperation as it jeopardizes the effective and uniform application of EU law. Allocation of powers that is prescribed in the Treaties were highly at stake according to the preliminary ruling of CJEU ${ }^{33}$.

The BGH set aside the arbitral award. As it was mentioned before, the seat of the arbitration was in Germany. So German Arbitration $\mathrm{Act}^{34}$ is applied to the arbitral award in the supervision process. BGH applied German Arbitration Act Section 1059(2)(1a) and placed his views on the lack of a valid arbitration agreement and reversed the High Regional Court's decision.

In most of the national codes and UNCITRAL Model Law, invalidity of the arbitration agreement, either formally or substantially, prescribed as one of the issues that could cause the vacation of the arbitral award. In addition, according to Article V/1(a) of the New York Convention, arbitration agreement must be valid in accordance with the law to which the parties have subjected it, or failing any indication thereon, under the law of the country where the award was made ${ }^{35}$. If at the request of the party against whom it is invoked proves that the arbitration agreement is invalid, recognition and enforcement of the award may be refused by the enforcing court.

There are several kinds of grounds regarding to the annulment of the arbitral award about the substantial invalidity of arbitration agreement ${ }^{36}$. In our case the main issue that makes the arbitration agreement invalid is the "illegality" of the arbitration agreement on the ground that it infringed the principles of EU Law since its supremacy shall all be recognized in the Member States.

\section{Concept of Public Policy}

Section 242 of German Civil Code (Bürgerliches Gesetztbuch-BGB) stipulates that, an obligor has a duty to perform according to the requirements of good faith, taking customary practice

\footnotetext{
${ }^{32}$ For the summary of the Higher Regional Court Decision please find BUNDESGERICHTSHOF BESCHLUSS I ZB 2/15 vom 3. März 2016 in dem Verfahren auf Aufhebung eines inländischen Schiedsspruchs, paragraph 11, juris.bundesgerichtshof.de /cgi-bin / rechtsprechung / document.py? Gericht= bgh\&Art=en\&nr=74612\&pos=0\&anz=1 (Accessed: 10.04.2021)

${ }^{33}$ Case C-284/16 Slovak Republic v. Achmea BV Judgment of the Court (Grand Chamber) of 6 March 2018, Request for a preliminary ruling from the Bundesgerichtshof, European Court Reports [2018], https://eur-lex.europa.eu/legalcontent/en/TXT/?uri=CELEX:62016CJ0284, (Accessed 15.04.2021).

${ }^{34}$ KASOLOWSKY, Boris/WENDLER, Carsten: Challenging and Enforcing Arbitration Awards: Jurisdictional KnowHow-Germany- in Rowley, J.William/Gaillard, Emmanuel and Kaiser, Gordon E. (eds) The Guide to Challenging and Enforcing Arbitration Awards, David Samuels, London 2019, p.300. For the text of the German Arbitration Act see: https://sccinstitute.com/media/29988/german-arbitration-act.pdf, (Accessed:10.04.2021).

${ }^{35}$ To speak about a valid arbitration agreement, first we must look to the Article 2 of the New York Convention. Article 2 provides for details about the formal validity of the arbitration agreement; however, we could not find any condition regarding the substantial validity of the arbitration agreement in the Convention. New York Convention rrefers to a national law of which the parties have chosen or the law where the award was made: SILACI KORKMAZ, Melis: New York Konvansiyonu Uyarınca Tahkim Anlaşmasının Geçerliliği ve Ehliyet, İstanbul 2020, s.58.

${ }^{36}$ Fraud and fraudulent inducement, mistake, lack of consideration, unconscionability, asymmetrical arbitration agreements, inconvenient arbitral situs, statutes of limitations, termination of arbitration agreement, insolvency, impossibility and frustration, defenses to standard form contracts and illegality are the most frequently causes regarding to the substantive validity of international arbitration agreements: BORN, Gary: International Commercial Arbitration, Vol I, Ed.3, Wolters Kluwer, Alphen aan den Rijn 2021, s.907.
} 
into consideration. The principle of good faith may preclude a party from invoking a ground for setting aside an award if that party expressly and unconditionally invoked an arbitration agreement prior to the proceedings to persuade the other party to initiate arbitration, only to argue in the arbitration and subsequent enforcement proceedings that the arbitration agreement was invalid ${ }^{37}$. In the present case BGH declared that Section 242 of German Civil Code should be applied as part of the procedural public policy of Germany. On the other hand, the Court admitted that contradictory behavior by a party is generally permitted. It only becomes abusive if the other party has trusted that behavior or if other special circumstances make the exercise of the right appear to be unlawful. In the dispute which forms the subject matter of the BGH judgment, no grounds for trust existed for the Netherlands Insurance Group. There are also no special circumstances that made the exercise of the right appear to be unlawful. In this situation, Section 242 of German Civil Code was applied as one of the mandatory rules of German Law, which is accepted as "rules of public policy" ${ }^{38}$.

Likewise, in Eco Swiss case one of the provisions of a German Law which is qualified as a mandatory rule was considered as a rule of public policy. This approach must be criticized that the Court could not be aware of the distinction between "domestic" and "international public policy" that the latter should be the main institution in the "annulment" or "enforcement" procedure.

The important part of the decision of the BGH is the statement that the arbitration award should not be set aside for breach of EU law provisions on public policy ${ }^{39}$.

As a final remark, "illegality" of arbitration agreement is different from "illegality" of arbitral awards ${ }^{40}$. Illegality of an arbitration agreement could rarely be seen. However if the arbitration agreement is against the mandatory rules of the law that supervises the substantial validity of the arbitration agreement, the court of the seat shall render a decision that the arbitration agreement is invalid ${ }^{41}$. On the other hand, the notion of public policy in private international law is regarded with the policies underlying the rules of the forum. It has to be understood as being a much narrower concept than the function in domestic law. When BGH characterized the Section 242 of German Civil Code as a rule of public policy, this characterization should be the subject of criticization, because Section 242 of BGB should be characterized within the category of domestic public policy, and domestic public policy is only functional in circumscribing the applicable law to the case. As annulment and enforcement conditions, adjudicators should only take into consideration the international public policy. At the end, BGH interpreted the "public policy notion" in duly manner by setting aside the achmea arbitral award according to Section 1059(2)(2b) ${ }^{42}$ instead of Section $1059 /(2)(2 b)^{43}$ of the Germen Arbitration Act.

\section{B. PL Holdings v. Poland}

\section{General Overview}

PL Holdings, which was incorporated under the Luxembourg law and registered in Luxembourg, initiated arbitration proceedings against Poland on 26 November 2014 according to the investment treaty that was concluded between the Republic of Poland and Luxembourg/Belgium whichentered into force on 2 August 1991. The seat of arbitration was Stockholm. PL Holdings claimed that Poland had violated its obligations under the investment treaty by expropriating PL Holdings' assets in Poland. On 28 September 2017, the arbitral tribunal rendered their final arbitral award in the same arbitral proceedings. According to the award, Poland undertook to pay

\footnotetext{
37 "The BGH's Achmea Decision: Arbitration Clauses In "Intra-EU BITs" Are Invalid" (Intra EU), https://www.clearygottlieb.com/-/media/files/alert-memos-2018/the-bghs-achmea-decision--arbitration-clauses-inintraeu-bi.pdf, (Accessed: 10.03.2021).

${ }^{38}$ Intra EU, s.3.

${ }^{39}$ SCHEU, Julian/NIKOLOV, Petyo: "The setting aside and Enforcement of intra-EU investment arbitration awards after Achmea", Arbitration International, 36, 2020, p.264.

${ }^{40}$ BORN, Vol. I, p.953.

${ }^{41}$ Let us assume that Turkish law applies to the substantive validity of arbitration agreement. According to Article 27 of Turkish Code of Law of Obligations,..." the contracts that are contrary to the.... mandatory rules of the Turkish Law are invalid". So an arbitration agreement that infringes the basic mandatory rules of Turkish law is deemed to be invalid: SARIÖZ-BÜYÜKALP. A. İpek: "Uluslararası Tahkimde Tahkim Anlaşmasının Hükümsüz, Tesirsiz Veya İcrasının İmkansız Olması Kavramları", Dokuz Eylül Üniversitesi Hukuk Fakültesi Dergisi, Prof. Dr. Hakan PEKCANITEZ'e Armağan, 16, Özel Sayı 2014, s.2038.

42 ...." 2. the court finds that a) the subject-matter of the dispute is not capable of settlement by arbitration under German law; or b) recognition or enforcement of the award leads to a result which conflicts with public policy (ordre public).

43 ...." 2. the court finds that a) the subject-matter of the dispute is not capable of settlement by arbitration under German law; or b) recognition or enforcement of the award leads to a result which conflicts with public policy (ordre public).
} 
653.639.384 Polish Zloty included interests to PL Holdings ${ }^{44}$. Poland applied to the Sweden Court of Appeal (SVEA) in order to persuade the court to set aside the arbitral award. SVEA has concluded that the arbitral awards are not invalid. SVEA issued that the arbitral awards could not be vacated regarding the invalidation of the arbitral awards or on the grounds of public policy. SVEA also did not find any infringement concerning the validity of the arbitration agreement. On the other hand, SVEA has rendered a decision regarding a minor part of the final arbitral award. According to Swedish Arbitration Act ${ }^{45}$ Section 34 Paragraph I Item 2, an award may be wholly or partially set aside upon motion of a party if the arbitrators have made the award after the expiration of the period stipulated by the parties, or where the arbitrators have otherwise exceeded their mandate. The arbitral tribunal issued an additional arbitral award regarding pre-award interest after the deadline expired. Due to this belated decision regarding the pre- award interest, SVEA vacated this minor part of this final arbitral award ${ }^{46}$

\section{Reasoning of the SVEA Court}

SVEA stipulated that Member States, in individual cases, could enter an arbitration agreement with an investor, i.e., based on an expression of party autonomy. Important conclusion from this expression that notwithstanding the Achmea ruling, the Member States do not have responsibilities to set a system that ensure the full application of EU Law in arbitration ${ }^{47}$.

In the end, SVEA found that the concept of public policy that receives consideration according to the national arbitration rules should not applied in the PL Holdings v. Poland Case.

Firstly, SVEA compared the consequences of Eco Swiss ruling ${ }^{48}$ with this case. According to the SVEA, it should be underlined that the incompatibility of arbitration clause with the public policy is different from the content of the arbitral award incompatible with the public policy. SVEA reiterated that in this case consequences of this arbitral award was not manifestly incompatible with ordre public.

Secondly, as already stated by the Court of Appeals, it can be concluded from the Achmea ruling that the CJEU distinguished between what the court refers to as commercial arbitration based on the party autonomy, and a mechanism for resolving disputes between Member States where an investor in a Member State may initiate arbitral proceedings against another Member State before an arbitral tribunal whose jurisdiction that Member State is obligated to accept. The Court of Appeals has already noted that this does not prevent Member States, in individual cases, from entering into an arbitration agreement with an investor, i.e. based on an expression of party autonomy.

The Swedish Court read the Eco Swiss Judgment in an extremely narrow manner and did not take into consideration the norms of European public policy that lead to the conclusion that giving effect to an intra-EU ISDS clause would violate the EU law dimension of public policy ${ }^{49}$.

\section{CONCLUSION}

Today, still, the business environment is inclining towards arbitration as one of the preferred forms of alternative dispute. If you compare arbitration with proceedings ofthe national courts, it is still efficient, confidential and time saving. The parties to the arbitration are turning party autonomy to a good account so they could easily escape from the harsh national court processes. At the same time, the parties involved in the development of the arbitral process should have issued all their

\footnotetext{
${ }^{44}$ SVEA Court of Appeal, Ruling 22 February 2019 Stockholm, Judgment of the Court of Appeal, p.5, (SVEA Court Report), https://www.italaw.com/sites/default/files/case-documents/italaw10447.pdf,(Accessed:15.04.2021).

45 The Swedish Arbitration Act, https://sccinstitute.com/media/37089/the-swedish-arbitration-act.pdf, (Accessed 18.06.2021).

${ }^{46}$ SVEA Court Report, p.85.

${ }^{47}$ SVEA Court Report, p.48.

48 In Eco Swiss case as we mentioned before, CJEU found that infringing a fundamental EU regulation which is indispensable for the functioning of the EU should be construed as manifestly incompatible with ordre public.

${ }^{49}$ SCHEU/NIKOLOV, p.264.
} 
allegations and defenses so that after the arbitral award is rendered, the winning party may expect the losing party to comply with the arbitral award voluntarily.

On the other hand, sometimes the losing party, who is not satisfied with the consequences of the arbitral award may request the set aside or the non-recognition/non-enforcement of the award. So the final efficacy of foreign arbitration awards relies on domestic courts.

Even though there are debates as to whether the "public policy" referred to in the New York Convention refers to "international public policy" or the national public policy, many countries have been guided by internationally held concepts of public policy.

The Eco Swiss case is one of the cases that should be criticized. The rules of EU Law should not be construed and qualified within the context of "public policy". Only postulates, ideas, values, or abstract rights may be deemed to fall within the context of public policy.

Next, the decisions of the Courts mentioned in this article perceive the notion of public policy in different ways when supervising the arbitral awards. As we understand it, the notion of "public policy" should not function as a tactical barrier in international arbitration. Especially, as prescribed in PL Holdings v. Poland, the notion of public policy was construed very narrowly. The mandatory rules of law should not be qualified in the context of public policy. Since "public policy" concepts are regarded as the "ancillary rules of private international law", they should be interpreted very narrowly. Mandatory rules could be qualified as "overriding" and may be applied by the judges and arbitrators by simply dismissing the classical "Savigny method".

Lastly, in both BGH decision that supervise the Achmea v. Slovak Republic arbitral award and SVEA decision that supervise the PL Holdings v. Poland arbitral awards, the judges, however interpreted the concept of public policy more accurately and they did not prefer to apply the public policy notion to set aside the arbitral awards. Although the judges were not quite capable of separating the notions of mandatory rules and public policy, at least SVEA refrained from damaging the effectiveness of the awards in $P L v$. Poland by not invoking the notion of public policy which is no doubt a dangerous weapon against the international commercial arbitration regime that should be protected for common good as it is so precious for the global commercial life. 


\section{REFERENCES}

AKINCI, Ziya: Milletlerarası Özel Hukuk, Vedat Kitapçılık, İstanbul 2020.

AKINCI, Ziya: Milletlerarası Tahkim, 5.Baskı, Vedat Kitapçılık, İstanbul 2020.

ATAMAN-FİGANMEŞE, İnci: “Devletlerarası Sözleşmelerde Yer Alan Tahkim Klozlarının Yatırımcılara Yapılmış Tahkim Anlaşması Akdetme Önerisi Olarak Kabulünün Ev Sahibi Devletler Bakımından Doğurduğu Olumsuz Sonuçlar”, in ÖZDEMIR-KOCASAKAL, Hatice/BALKAR, Süheyla (ed.), Tahkim Anlaşması, On iki Levha Yayınları, İstanbul 2020, s.103-131.

ATAMAN-FİGANMEŞE, İnci: "Manufacturing Consent to Investment Treaty Arbitration By Means of the Notion of "Arbitration Without Privity" (Manufacture), Annales de la Faculte de Droit d'Istanbul, XLIII(LX), 2011, p.187-201.

BARRACLOUGH, Andrew/WAINCYMER, Jeff: "Mandatory Rules of Law in International Commercial Arbitration", Melbourne Journal of International Law, 6(2), 2005, s.205-244.

BERMANN, George A.: "Navigating EU Law and Law of Arbitration,” Arbitration International, 28(3), 2012, s.397-446.

BORN, Gary: International Commercial Arbitration, Vol I, Ed.3, Wolters Kluwer, Alphen aan den Rijn 2021.

BORN, Gary, International Commercial Arbitration, Vol.III, Ed.3, Wolters Kluwer, Alphen aan den Rijn 2021.

BUCHANAN, Mark A.: "Public Policy and International Commercial Arbitration", American Business Law Journal, XXVI (III), Fall 1988, p.511-531.

ÇELIKKEL, Aysel/ERDEM, Bahadır: Milletlerarası Özel Hukuk, 14.Bası, Beta Yayınları, İstanbul 2016.

DEMIR GÖKYAYLA, Cemile: Yeniden Kamu Düzeni, Onuncu Yılında MOHUK Sempozyumu, in Tanrıbilir, Feriha Bilge/Gümüşlü Tunçağıl, Gülce (ed.), Sempozyum 7-8 Aralik 2017, Adalet Yayınevi, Ankara 2018, s.85-98.

DOLINGER, Jacob: "World Public Policy: Real International Public Policy in the Conflict of Laws", Texas International Law Journal, XVII(II) Spring 1982, p.167-193.

EKŞİ, Nuray: "Yargıtay Kararları Işığında Yabancı Hakem Kararlarının Tenfizinde Kamu Düzeni”, Public and Private International Law Bulletin, Prof. Dr. Cemal Şanlı’ya Armağan,40(1), 2020, s.143-201

FRY, James: "Desordre Public International under the New York Convention: Wither Truly International Public Policy”, Chinese Journal of International Law, VIII, 2009, p.81-134.

FUMAGALLI, Luigi: "Mandatory Rules and International Arbitration: An Italian Perspective", ASA Bulletin, 16(1), 1998, s.43-59.

GRUSIC, Uglješa/HEINZE, Christian/MERRETT, Louise/MILLS, Alex/GARCIA-CASTRILLON, Carmen Otero/TANG, Zheng Sophia/TRIMMINGS, Katarina/WALKER, Lara: Cheshire, North \& Fawcett Private International Law-Edited by Paul Torremans, Ed.15, OUP, New York 2017.

GÜNGÖR, Gülin: Türk Milletlerarası Özel Hukuku-Kanunlar İhtilafı Hukuku Milletlerarası Usul Hukuku, Yetkin Yayınları, Ankara 2021.

HAY, Peter: Advanced Introduction to Private International Law and Procedure, Edward Elgar Publishing, Cheltenham/Northampton 2018.

HORVATH, Gunther J: "The Duty of the Tribunal to Render an Enforceable Award”, Journal of International Arbitration 18(2), 2001, p.135-158.

IDOT, Laurence: “Arbitrage et droit de la concurrence”, Revue des droits de la concurrence, Concurrences 4, 2010, note.64, s.14,www.concurrences.com, (13.04.2021).

JEMIELNIAK, Joanna: "Transnationalization of Domestic Law in International Commercial Arbitration Through Comparative Analysis: Challenges for Legal Profession, Contemporary Asia Arbitration Journal, 7(2), 2014, s.309-340.

KÁPOSZNYÁK, Aliz: "Intra-EU Arbitral Awards After Achmea: Recognition and Enforcement Within the European Union Under the New York Convention" in Z. Meškić et al. (eds.), Balkan Yearbook of European and International Law 2019, 2020, p.69-89.

KASOLOWSKY, Boris/WENDLER, Carsten: Challenging and Enforcing Arbitration Awards: Jurisdictional Know-How-Germany- in Rowley, J.William/Gaillard, Emmanuel and Kaiser, Gordon E. (eds) The Guide to Challenging and Enforcing Arbitration Awards, David Samuels, London 2019, p.300-315. For the text of the German Arbitration Act see: https://sccinstitute.com/media/29988/german-arbitration-act.pdf, (10.04.2021).

KEGEL, Gerhard/SCHURIG, Klaus: Internationales Privatrecht, 9. Auflage, Beck, München 2004.

LALIVE, Pierre: "Transnational (or Truly International) Public Policy and International Arbitration", in Comparative Arbitration Practice and Public Policy in Arbitration, ICCA Congress Series, III, 1986, Kluwer Law International, Aaan den Rijn 1987, p.258-318.

MAURER, Anton.: The Public Policy Exception under the New York Convention-History, Interpretation and Application, Revised Edition, JurisNet, New York 2013. 
MAYER, Pierre: "Mandatory Rules of Law in International Arbitration", Arbitration International, 2 (4), 1986, s.274-293.

NOMER, Ergin: Devletler Hususi Hukuku, 22.Bas1, Beta Yayınları, İstanbul 2017.

PARK, William: The Specificity of International Arbitration: The Case for FAA Reform, Vanderbilt Journal of Transnational Law, XXXVI, 2003, p.1242-1311.

SARIÖZ-BÜYÜKALP. A. İpek: "Uluslararası Tahkimde Tahkim Anlaşmasının Hükümsüz, Tesirsiz veya İcrasının İmkansız Olması Kavramları”, Dokuz Eylül Üniversitesi Hukuk Fakültesi Dergisi, Prof. Dr. Hakan PEKCANITEZ'e Armağan, 16, Özel Sayı 2014, s.2015-2061.

SCHEU, Julian/NIKOLOV, Petyo: "The setting aside and Enforcement of intra-EU investment arbitration awards after Achmea" Arbitration International, 36, 2020, p.254-274.

SILACI KORKMAZ, Melis. New York Konvansiyonu Uyarınca Tahkim Anlaşmasının Geçerliliği ve Ehliyet, İstanbul 2020.

SHENOY, Nivedita: "Public Policy under Article V (2)(b) of the New York Convention: Is there a Transnational Standard", Cardozo Journal of Conflict Resolution, XX, 2018, p.77-103.

STORSKRUBB, Eva: "Navigating EU Law and the Law of Arbitration-From the Horizon of Commercial Arbitration in Sweden", In: Eric Bylander, Anna Jonsson Cornell, Jakob Rangwaldh (ed.), Forward! - Вперёд! - Framåt!: Essays in Honour of Prof Dr Kaj Hobér Uppsala: Iustus förlag, Uppsala 2019, p.285-309.

ŞANLI, Cemal/ESEN, Emre/ATAMAN-FİGANMEŞE, İnci: Milletlerarası Özel Hukuk, Bası.8, Vedat Kitapçılık, İstanbul 2020.

TEKİNALP, Gülören: Milletlerarası Özel Hukuk Bağlama ve Usul Hukuku Kuralları, 13.Bası, Vedat Kitapçılık, İstanbul 2020.

TİRYAKİOĞLU, Bilgin.: Yabancı Mahkeme Kararlarının Tanınması ve Tenfizinde Kamu Düzenine Aykırılık, Yabanı Mahkeme ve Hakem Kararlarının Tanınması ve Tenfizinde Güncel Gelişmeler, Edt. Süheyla Balkar BOZKURT, Sempozyum 14 Ekim 2016, On iki Levha, İstanbul 2018, s.83-95.

TİRYAKİOLU, Bilgin: Taşinir Mallara İlişkin Milletlerarasi Unsurlu Satim Akitlerine Uygulanacak Hukuk, AÜHF Döner Sermaye Yayınları, Ankara 1996. (Taşınır) 